\author{
Patrycja Chlebus-Grudzień \\ Jagiellonian University \\ Faculty of Philosophy \\ Institute of Sociology \\ patrycja.chlebusgrudzien@gmail.com
}

\title{
SELFIE AT A MUSEUM: DEFINING A PARADIGM FOR AN ANALYSIS OF TAKING (SELF-PORTRAIT) PHOTOGRAPHS AT MUSEUM EXHIBITIONS
}

\begin{abstract}
Due to the development of social media, posting one's photos is becoming increasingly popular; they often take the form of, so called, 'selfie'. The phenomenon of photographing oneself has also occurred in cultural institutions, including museums. The museums are implementing various strategies of reacting to people taking pictures of themselves with exhibits at the background. The article presents an analysis of these reactions, and, based on that, various ways of defining the functions and role of the contemporary museum. The author also attempts to provide an answer to the following question: is posting photographs by visitors an element of creating their own image ('the Culture of Narcissism'), or is it rather a form of interaction with heritage, of a dialogue with the presented contents ('remix culture')?
\end{abstract}

Keywords: selfie, museum, tourism photography, Culture of Narcissism, remix culture.

\section{INTRODUCTION}

Photographing at museum exhibitions is an increasingly popular phenomenon, more and more frequently commented on by museum workers, as well as visitors. It starts to be so socially significant that it is worth scientific analysis. However, the specificity of this phenomenon causes that there is a lack of tools, and perhaps more importantly, analytical categories to describe and examine private photographs from exhibitions. The aim of the article is, first and fore-most, to enter the subject of photos of museums' visitors into the wider context of sociological studies regarding photography and its relationships with tourism, as well as to identify perspectives and methods of analysis useful in scientific research. Such a study will allow to avoid triviality and super-ficiality of considerations, which often occur in scientific analysis when they concern phenomena related to new technologies and social media. The article is a kind of exploratory work which becomes the basis for the future construction of effective research tools.

\section{DESCRIPTION OF THE PHENOMENON}

Social networking sites have become a space for continuous sharing and dissemination of personal experiences, undertaken activities, or encountered situations - usually in the form of the users' photographs. Published photographs include those that were taken in museums and users boast about their visits to such cultural institutions. They pose against a background of works of art, photograph themselves with exhibits, and report on their visits to exhibitions. And although a camera is not a new tool in a museum - for instance, it helps to document the collection - it is the visitors posting their photographs on the internet that is considered by many to be the surprising phenomenon, a behaviour that does not fit into the traditional vision of visiting a museum. For a long time, when tourists took pictures, they would end up in their home collection, becoming private souvenirs shown to family members and friends. Currently, access to tourist photographs from museums is much easier. People share their impressions usually without limiting the number of potential viewers. Pictures on social networking sites are no longer just personal images that evoke memories but become widespread. 
The increasing number of published photographs depicting people during their visits to the museum allows it to be stated that this is a phenomenon which should be of interest to both museologists and researchers. Currently, Instagram ${ }^{1}$ has $11,437,516$ photographs with the hashtag: \#museum, while \#muzeum appears in the captions of 136,264 photographs. There are also hashtags for particular facilities (for example - \#uffizi: 129,238 photographs, \#metropolitanmuseum ofart: 200,635 \#britishmuseum: 340,978, \#louvre: $1,935,851)$. These numbers indicate that this is not marginal or representative of only individual behaviours. Of course, many tourist attractions are a much more popular subject for published photographs, but a visit to a museum is starting to become an experience that users want to share with others increasingly often. This popularity is influenced by celebrities who report on their visits to exhibitions as well (e.g. Beyoncé, Kim Kardashian). When looking at the various ways of spending free time demonstrated on social networking sites, it becomes apparent that attending an exhibition is treated by users as everyday behaviour.

In a large number of cases, visiting museums is presented as a natural consequence of visiting a new city or spending free time. Neither those posting the photographs, nor those commenting on them, describe these visits as an extraordinary event available to a few people only. Pictures from various museums can be found among other ones, such as at a restaurant, a cinema, or a concert. As a result, museum institutions are becoming recognizable and a part of everyday online life. At this point, it should be emphasized that exhibitions, in fact, encourage people to take pictures more than other forms of entertainment or education. Museums are visual by nature. They have an arranged space for the visitors. This is somewhat reminiscent of a set design: a specially created world that is just waiting to be captured. Exhibitions present some unique and attractive objects, displaying them in a very thoughtful way. Visitors entering the exhibition do not have to create a situation interesting enough to be worth capturing. They are in a place that already meets this criterion. The entire exhibition consists of attractive and potentially interesting scenery. The visitors' only dilemma is what they will pay attention to, what they will photograph and what they will share with other internet users.

Museologists notice the growing popularity of online photo sharing. They themselves describe the behaviour of visitors who photograph themselves with exhibits. They react to this both with satisfaction, seeing it as an opportunity to effectively for promotion and a way of attracting people to cultural heritage, while others criticize it strongly, stressing the issue of the physical danger to exhibits and the trivialization of themes. Łukasz Maźnica distinguishes four strategies adopted by museum institutions: 1) negation, 2) relative passivity, 3) acceptance in a controlled framework, and 4) enthusiasm (MAŹNICA 2016). The first one manifests itself as a total ban on taking photographs within the exhibition. The second one means allowing photography if you follow restrictions, such as not using selfie sticks. The third type of reaction refers to a situation when, with simultaneous prohibition, there is a place with replicas of exhibits where you are allowed to take photographs - this helps to avoid the risk of damage to original items. Enthusiasm, on the other hand, means not only consent but also encouragement to take and publish photographs, for example, through online campaigns or contests for the most interesting image from the museum. The way a given institution reacts certainly indicates how it defines its tasks and how it perceives communication with its own audience.

\section{SOCIAL SIGNIFICANCE OF TAKING PHOTOGRAPHS}

The phenomenon of taking photographs in a museum, although recognized and widely discussed, is still often not treated seriously, seen as a trend that is not worth academic reflection. However, an analysis of photographs published on the internet can lead to the improvement in understanding about the mechanisms of contemporary communication, and the reception of culture. Here discussion will be presented of which fields can benefit from an analysis of photographs from museums, which categories can be developed, and from what perspectives can they be analysed. During theoretical considerations and research into such behaviours, it should certainly be remembered not to treat photographs on the internet in isolation from other types of photography. They are not a completely new, different and undiscovered creation. They arise from the long-existing need to photograph and view the resulting images. That is why it is so important, at the initial stage of analysis, to determine the social meaning of taking pictures.

A camera is for documenting, extracting a single moment from many others and processing it into a specific, permanent image. The given situation becomes fixed in this process and has its representation. Konecki even calls photograph a 'memory prosthesis'. He says that "by photographing, we create a specific image in the present, of what will soon be the past, for the future" (KONECKI 2005). The picture is a testimony of the past moment, it creates an easily accessible means to build a narrative about the past. 
The captured image (whether in physical or digital form) refers to human experiences. It should be remembered that the camera is a tool that inextricably connects what is photographed with the person who releases the shutter. Although at first glance, one can only see what is visible in the picture, each frame represents a very subjective perspective of a given person. Literature points to the illusory objectivity of a picture (SONTAG 2017, BOURDIEU 2012). A photographer is not passive, the camera is not thoughtlessly used when creating a faithful copy of reality. A picture does not allow for impartial or neutral cognition (although it creates the appearance of such). A photograph is always an interpretation, both through a decision on what to photograph and the way it is presented.

Photography can be described as a selection process. A simple act, like using a camera, involves presenting a way of perception, creating a personal vision of a given event, person, or object. François Soulages, describing the issues of private photographs, coined the term 'photographic cogito'. The author links the act of photography with an indication of one's own presence, emphasizing one's own existence. It shows that a private photograph 'seems to be not only a witness, but above all a proof of our life, a trivial metamorphosis and anonymous existence in a way that deserves to be experienced' (SOULAGES 2007). A person who takes a picture expresses: 'I was and I have experienced'. Photographs also have the ability to give value to their content presented. What is captured is perceived as significant and important, because someone decided to capture it, someone noticed it and found it interesting. The choice inherent in this process makes it possible for the camera to determine what is worth watching and remembering, as well as what should be hidden and not shown.

In addition to the extremely important creative act, reception is a part of photography as well. A picture is a message, a medium in the communication process. After all, it is made to show something. Even if it is not created to be shared, it becomes a potential carrier of ideas. Importantly, the photographic message is not always read in accordance with the intention of the author. A photograph detached from the original context can often create new meanings and interpretations. Its bonding function is also worth mentioning. M. PIEJKO (2008) points to a series of practices taking place around photography (shared taking of photographs, viewing albums, uploading, placing in important places) that help maintain contact and create a common identity. This is most visible in families, where photographs of time spent together or relatives themselves often become an axis of jointly shared stories. Similar behaviours can also be seen in social circles. The characteristics of photography described above (its specificity, consequences, and functions) also apply online. These also document the past and become the basis of memory, testify to the existence of the photographer and selectivity. They also have the ability to ennoble and give significance to given situations, they perform communication and bonding functions.

It is also worth emphasizing that a camera favours the user, allows a user to evaluate situations, but also to modify them. S. SONTAG (2017) describes it with the following words: "Photography has the right to interfere with, invade, or to ignore whatever is going on". A person with a camera in their hand gains a better access to events, they can approach more closely, and obscure the view of others. The logic of a privileged photographer starts to be naturally accepted by an increasing number of people. The fact of taking a picture, in their opinion, entitles them to violate the existing restrictions. This may create a tension when visitors who are in a frenzy of taking pictures appear in a place where other values are preferable, for example in a museum. The exhibits do not need confirmation of their uniqueness from visitors, they have obtained it by being placed there by the curators of the exhibition. Museologists do not always want the visitors to be the ones that photograph the exhibition. Museum institutions wanting to maintain respect for the exhibited items impose limited access to them.

\section{THE DOMINANCE OF PHOTOGRAPHY IN THE CONTEXT OF TOURISM}

Attempts to reduce the number of people taking photographs are difficult nowadays, since they conflict with emerging social trends, which increasingly privilege the image. Visual culture is described as dominant, which makes photography a natural, universally accepted, and even mass activity. It can be defined as the indisputable norm. M. BOGUNIABOROWSKA \& P. SZTOMPKA (2012) notes: "today, we are all photographers. Among the many roles that modern people play, the role of a photographer and the creator of images seems to be one of those essential to our existence in the social universe of the world. (...) Being a photographer of social life means not only the physical taking of pictures, but also the perception of reality in terms of images, through frames, segments and sections of reality." Visual representations are treated with greater interest and recognition, they are the main ones that influence social imagination and behaviour. M. BOGUNIA-BOROWSKA \& P. SZTOMPKA (2012) points to five manifestations of visual culture. 
He writes that we are dealing with a society of:

- icons - everyday life's high saturation with visual impressions; popularity of images in very diverse forms,

- performance - dramatisation and aesthetisation of even the most ordinary situations; anticipating the reactions of others (the audience) and adapting one's own activities on this basis,

- self-presentation - a tendency to increase the effort put into creating a positive image of oneself,

- design - the growing importance of the attractiveness of products; when assessing them, the aesthetic function is as important as its usefulness,

- voyeurism - the need to watch; giving the wider public access to areas that were previously hidden (e.g. private life); the phenomenon of widening visibility.

Pictures are taken nearly everywhere and of nearly everything. However, it is in the field of tourism that the phenomenon is intensified most. Traveling has always been associated with the need for documentation and commemoration. Tourist trips create many opportunities to experience something that can be shown off in front of family, friends. Often, it is the vacation period that generates most of the pictures taken, it is full of events that, according to the travellers, are worth capturing. This should not come as a surprise when one considers the fact that tourism itself is defined in opposition to everyday life. The 'tourist's gaze' seeks for what is unusual, extraordinary, different from usual experience (...). Pictures allow you to capture this uniqueness and change experiences into images. S. SONTAG (2017) analyses the behaviour of tourists in the following way: "It seems positively unnatural to travel for pleasure without taking a camera along. Photographs will offer indisputable evidence that the trip was made. (...) Photographs document sequences of consumption carried on outside the view of family, friends, neighbours."

A modern tourist needs a camera, they want to deliver a report from a trip, in order to be able to recall what they have experienced, and to testify to others. Travel photographs also influence the tourist's imagination about a given place. Before a person goes on a planned trip, the attractions are usually known, what the places will look like. Particular locations have their own representations that strongly define expectations. Travelers often go to see what they have already seen in pictures. Tourist photography not only allows one to communicate about ways of spending free time, but is also a significant factor determining travel choices, and thus the structure of trips.

\section{WAYS OF ANALYSING PHOTOGRAPHS TAKEN IN A MUSEUM}

Museums as objects of cultural tourism have to deal with mass photography as well. Regardless of whether museologists regard this as a threat or a chance for development, photographs posted on social media can be a source of useful information for them. They become very valuable material for researchers as well. Here an exploratory analysis based on photographs (and their captions), using the Instagram application, from the National Museum in Kraków and from the British Museum in London². Not only selfies (photographs with their authors in them) were taken into account, but all those that included the hashtag of the museum. Three ways of discussing this type of photography were distinguished: 1) presenting one's own image; 2) relation to the museum; 3) interaction with heritage. These categories indicate what kind of information can be obtained by analysing photographs from a museum and what processes and mechanisms they can combine with. These three categories do not exclude other types of analysis. The created typology is a suggestion on how to work on such data.

\section{PHOTOGRAPH ANALYSIS}

\subsection{PRESENTING ONE'S OWN IMAGE}

Selfie photographs and any type of self-portrait sharing is described in many papers as a manifestation of a 'narcissistic culture'. They treat such photographs as a strategy of attracting attention, fulfilling the need of showing one's self to others (WAGNER 2015). This trend also speaks about narcissistic surfing, or a "compulsive need to leave a lot of personal information on the web, but also to search for information on one's self" (SZPUNAR 2016). Identifying online photographs with self-centred premises only seems to be an unfair evaluation, as well as a too superficial treatment of the phenomenon. The use of societal self-presentation (BOGUNIA-BORKOWSKA, SZTOMPKA 2012) allows a different perspective to be used. In the modern world, we are responsible for our own image. The processes of individualization have even made the creation of a distinctive and unique 'Project Self' an individual obligation (JACYNO 2007, DZIUBAN 2013). Identity is to a lesser extent imposed by groups and is more dependent on individual actions. This results in the need to build a positive impression independently, to create an interesting self-image. Otherwise, an accusation of leading an unreflective and passive social existence can be levelled. 
Pictures on the internet are an ideal tool for creating an interesting image. In addition, photographs from museums serve to present one's identity. People who decided to publish photographs from an exhibition stated that visiting exhibitions is an activity that fits the personality created ${ }^{3}$ by them. Although, there are sometimes so many photographs on individual profiles that they seem to be posted accidentally and chaotically, it is rare for people to publish images that are clearly in contradiction with their created image. The selection of the photographs shared may not always be conscious, but it presents a specific lifestyle. Considering the growing importance of self-presentation and the specificity of social media, Soulages' 'photographic cogito' can be considered a topical and accurate concept. Pictures posted on the internet become evidence that you are active. They are, first of all, a proof of spending time in an attractive way. Sharing photographs means that you have just experienced something that can be shared with a wider audience. On social networking sites, photographs are often a condition of being noticed. When analysing the photographs posted from visits to a museum, it should be remembered that choosing the right pose, the presented exhibit or the stylistics of the photograph are intended as a testimony of the author.

It is worth asking at this point how visitors present themselves in the pictures they post. The photographs analysed most often show users in their free time. They look relaxed, they wear casual outfits, they are often smiling. One of the most typical methods of photography in museums is one with the building or the exhibits in the background. It takes the form of a classic holiday memory, not unlike the photographs from a family album. The person stands in the foreground and there is an interesting object (sometimes more, other times less visible) in the background. An image of this type posted on social media is primarily a proof of one's visit. Even when photographs are browsed quickly it is easy to recognize who is in the picture and where it is located.

The second equally popular type shows visitors during the visit. In the photographs, people are viewing the exhibition, we can see their back or side while they are looking at a particular exhibit. There are also pictures showing materials for visitors being read. These types put great emphasis on the performed activity and emphasize interest and involvement. It can be concluded that the user went to the museum to learn about cultural heritage. They inform not only that someone was at the exhibition, but also that they were interested in it. All photographs from the museum published on social media suggest users' interest in art or culture. They also show in which cities particular people are and how they behave and the museum in which they take pictures, can be a way of enriching their image created on the internet.

\subsection{REPORT OF A VISIT TO A MUSEUM}

The photographs make it possible to determine ideas about the institution of the museum itself, as well as about individual facilities visited. The fact that photographs are posted showing them at an exhibition indicates that the museum is considered to be a place worth visiting. A visit to this institution is something they can boast about, they consider it an element that can contribute to the creation of a positive selfimage. Certainly, the museum is considered a place where you have contact with culture, where you can learn something new and see unique items. This is evidenced by photographs showing the activity of viewing the exhibition as well as descriptions emphasizing the uniqueness of the admired items. The opportunity to see original exhibits is still treated as an essential element of a visit to a museum.

Users publish their photographs from exhibitions without treating them as unusual or extraordinary events. Such photographs have the same premise as those presenting other forms of entertainment or education. This fact indicates that visitors do not treat institutions as a place to which only a limited number of people have access. There is no elitism on social networking sites, it is rather described as an institution that everyone visits (even if it is from time to time). It is worth emphasizing that in many photographs, users appear with their co-visitors. Taking photographs in a museum is a situation that is often shared with those close to us. A visit to the exhibition can therefore be an opportunity to meet people, make contact or build relationships. This perspective is emphasized by the fact that a museum can be a space not only for exploring cultural heritage, but also a place for personal experiences and for building relationships. This aspect of visits, often forgotten or underestimated by museologists, is very important for users.

Photographs posted by visitors do not come exclusively from exhibition rooms. People are also photographed in other places in the museum, in spaces that do not have exhibiting functions, like cafes and museum shops. Such photographs are a valuable source of information about how visitors use the entire facility. The museum is not only an exhibition for them, but also a place where they can rest, discuss or deepen their knowledge after looking at the exhibits. By comparing photographs from different parts of a museum, you can determine the attitude of its visitors. The branches of the National Museum in Kraków are a good example. Although it is a single 
organizational unit, pictures show that different branches evoke different ideas. For example, the main building is often associated with a large temporary exhibition. It is shown as a tourism space, in which you can learn and see a lot. Czapski's pavilion is presented as a more intimate place, where people spend their free evenings or come every day to sit in a café. It is received as targeted mostly at the residents of Kraków. The published photographs clearly show the differences between the different types of museum.

\subsection{INTERACTION WITH HERITAGE}

The main objective of an exhibition is to present elements of cultural heritage. Visitors can react to it very differently, with admiration, surprise, indignation or boredom. Museum visitors are characterized by varying levels of knowledge, different tastes and different experiences. During the visit, they learn specific information about the subject matter, but also create their own associations, and narratives about the exhibits. Contrary to the strategies often adopted by the curators of exhibitions, the reception of culture does not follow one of the top-down imposed methods but runs many - very individualized - courses (JENKINS 2007). This can be easily seen in photographs published on social media. These photographs allow people to show their own view of the work, to show what has interested the user. The following elements of interaction with heritage appearing on shared photographs have been distinguished:

- paying attention to detail - photographing details which are often part of a larger item, such as a sculpture or a painting;

- photographs taken from an unusual perspective - exhibits shown from different angles and places, non-schematic shots of a given item or work;

- posing with an object - copying scenes from works or incorporating exhibits into the created scene (e.g. conversations with a sculpture);

- reflections and thoughts - most often put in captions, sometimes appear as text inserted into the photo in the form of a short statement;

- collage of photographs - juxtaposing several photographs into one picture;

- creating inspired works - making drawings, sketches, graphics or paintings of specific exhibits or the entire visit;

- remixed pictures - a photograph that after being taken is modified by cutting and pasting elements from other photographs or images.
All of these elements serve to demonstrate issues that intrigued and inspired users. Visitors show in their pictures what made them laugh, what made them think. Exhibits are presented in new contexts, with original comments and unusual connotations. This fits in with the tendency called the remix culture, where the existing work becomes the basis for the emergence of others, where cultural content is constantly modified and reinterpreted (NACHER, GULIK \& KAUCZ 2011). Henry JENKINS (2007) points to convergence, understood as "seeking out new information and making connections between dispersed media content". Some published photographs epitomize the features of this phenomenon. You can, of course, treat such photographs as banal entertainment, but you cannot undermine that by taking them, people learn about cultural heritage, become familiar with it, start to identify with it and interpret it in their own way.

\section{CONCLUSION}

The three categories of analysis defined in this article allow the phenomenon of photography in a museum to be looked at from many aspects. The first perspective - creation of an image - makes this phenomenon one of the mechanisms of individualization and self-design. The second one provides knowledge about the reception of the museum. It also allows us to compare particular facilities. The idea of interaction with heritage makes the phenomenon part of broader processes of cultural reception and distribution. How visitors interpret the content they encounter and how it is given meaning can be discovered. For researchers, photographs from the museum, therefore, constitute inspiring data on the functioning of modern museums, and for museum professionals - a source of useful information about their audience.

\section{ENDNOTES}

1 Instagram - a social networking site for sharing photographs. The posts are in the form of photographs with captions and hashtags (preceded with the '\#' sign).

2 Most of the analysed photographs come from the period from September to November, 2017.

3 The word "created" is not used in a negative context here, it does not mean an artificially created personality, it does not serve to create an opposition to the real one. Using this term results from the assumption that a social researcher is not able to determine whether the real identity exists and what it is, but they have access only to its exposed manifestations. 


\section{BIBLIOGRAPHY}

BOGUNIA-BOROWSKA M., SZTOMPKA P. (eds.), 2012, Fotospoteczeństwo. Antologia tekstów z socjologii wizualnej, Społeczny Instytut Wydawniczy Znak, Kraków.

BOURDIEU P., 2012, Społeczna definicja fotografii, [in:] M. Bogunia-Borowska, P. Sztompka (eds.), Fotospoteczeństwo. Antologia tekstów z socjologii wizualnej, Społeczny Instytut Wydawniczy Znak, Kraków.

DZIUBAN A., 2013, Gry z tożsamością. Tatuowanie ciała w indywidualizujacym się społeczeństwie, Wyd. Naukowe Uniwersytetu Mikołaja Kopernika, Torun.

JACYNO M., 2007, Kultura indywidualizmu, Wyd. Naukowe PWN, Warszawa.

JENKINS H., 2007, Kultura konwergencji: zderzenie starych i nowych mediów, Wyd. Akademickie i Profesjonalne, Warszawa.

KONECKI K., 2005, Wizualne wyobrażenia. Główne strategie badawcze w socjologii wizualnej a metodologia teorii ugruntowanej, Przeglad Socjologii Jakościowej, I, 1.
MAŹNICA Ł., 2016, Selfie w muzeach - analiza zjawiska w kontekście działalności i roli społecznej muzeów, [in:] G. Stunża, K. Stachura (eds.), Kultura od nowa. Badania - trendy - praktyka, Instytut Kultury Miejskiej, Gdańsk.

NACHER A., GULIK M., KAUCZ P., 2011, Post-teorie i re-praktyki. Wprowadzenie do remiksu, [in:] M. Gulik, P. Kaucz, L. Onak (eds.), Remiks. Teorie i praktyki, Hub Wydawniczy Rozdzielczość Chleba, Kraków.

PIEJKO M., 2008, Skarby pamięci. Socjologiczna analiza fotografii rodzinnej, Przeglad Socjologii Jakościowej, IV, 3.

SONTAG S., 2017, O fotografii, Karakter, Kraków.

SOULAGES F., 2005, Estetyka fotografii. Strata i zysk, Universitas, Kraków.

SZPUNAR M., 2016, Kultura cyfrowego narcyzmu, Wyd. AGH, Kraków.

WAGNER E., 2015, Selfie Society: Narcissism and the Celebration of Mediocrity, Kindle Edition.

Article received:

15 February 2018

Accepted:

14 May 2018 